\title{
GEOTECHNICAL FACTORS GOVERNING SHEAR STRENGTH OF QUSEIR SHALE IN DAKHLA OASIS, WESTERN DESERT, EGYPT
}

\author{
El-Sayed Sedek Abu Seif ${ }^{a}$ and El-Sharif M. Abd Al-Aziz ${ }^{b}$ \\ a Geology Department, Faculty of Science, Sohag University, Sohag, Egypt \\ b Civil Engineering Department, Faculty of Engineering, \\ Assiut University, Egypt
}

(Received November 27, 2007 Accepted December 16, 2007)

\begin{abstract}
This paper presents an extensive study geotechnical factors controlling undrained shearing characteristics of Quseir Varigated Shale in central part of Dakhla Oasis. The clayey soil of Quseir Shale covers the floor of Dakhla Oasis. In recent years, the size of structures in this region has been increasing. The shearing behaviour of soils is of major concern for engineers, since the solution of stability problems in foundation engineering requires knowledge of the shearing strength of the underlying soil. The Quseir Shale in Dakhla Oasis consists of four layers (green gypsiferous shale graded downward into yellowish green shale, green shale and reddish gray shale). The clay minerals of the studied soil consisting of five species namely kaolinite was the predominant clay mineral present, smectite, illite, illite-smectite mixed-layer, and chlorite which arranged in a decreasing order of abundance. The geotechnical parameters of the studied clayey soils show a strong mutual relation between some measurements and undrained shearing parameters. The measured major stress $\left(\sigma_{1}\right)$ has a close direct proportional relation with sand\%, silt\%, kaolinite\%, calcium carbonate content and depth. The effective cohesion $(C)$ has a close direct proportional relation with clay fractions, initial water content, and smectite\%.
\end{abstract}

KEYWORDS: Undrained shear strength; Clay Minerals; Quseir Shale; Western Desert; Egypt.

\section{1- INTRODUCTION}

During the past two decades Egypt has witnessed a rapid and substantial development of its infra-structure involving widespread construction of roads, low rise housing and public buildings. Thus, an extensive research program was initiated to study the factors controlling the geotechnical properties of the soils and rocks in theses regions. For this purpose geotechnical and mineralogical studies were carried out utilizing undisturbed core samples collected from boreholes at a number of locations. This study presents the background to the geological investigations and the detailed results of tests on clayey soils from two specific locations.

This paper describes a close up study that evaluates the shear strength and deformation characteristics of clayey soil of Quseir Varigated Shale in central part of Dakhla Oasis. The floor of Dakhla Oasis nearly covered by clayey soils of Quseir Shale. In recent years, however, the size of structures in this region has been 
increasing. Thus, evaluation of the engineering characteristics these soils has become an important issue for design and construction these areas. The shearing behaviour of soils is of major concern for engineers, since the solution of stability problems in foundation engineering requires a knowledge of the shearing strength of the underlying soil [1].

Most of the current design practices in geotechnical engineering are based on strength criteria, where shear strength is considered as one of the most important design parameters. Any soil element subjected to a particular loading condition has two well-defined shear strengths, namely the peak strength corresponding to the maximum deviator stress and the steady state strength corresponding to the critical state [2]. The strength of a soil can be inferred from its shearing resistance. The shearing behaviour of soils is of major concern for engineers, since the solution of stability problems in foundation engineering requires knowledge of the shearing strength of the underlying soil. The design of foundation in fine-grained soils is frequently complicated by anisotropy of shear strength within the soil. This anisotropy may be due to the subhorizontal alignment of the platy clay-mineral grains and the diagenetic bonds between them [3]

The present paper represents an extensive studying the factors controlling the undrained shearing characteristics of Quseir Shale in central part of Dakhla Oasis. To achieve this purpose two sites were selected the first one was in Teneida, "site I" and the second was in Balat "site II". Undisturbed and disturbed samples were extracted and tested in a laboratory, to determine their physical and mechanical properties.

\section{2- GEOLOGICAL SETTING}

The Dakhla Oasis is about $490 \mathrm{Km}$ west of Assuit (City of the upper Egypt). It is bounded approximately by the latitude $25^{\circ} 35^{-} \mathrm{N}$, to $26^{\circ} 00^{-} \mathrm{N}$ and longitude $28^{\circ} 10^{-}$ $\mathrm{E}$, to $28^{\circ} 54^{-} \mathrm{E}$. The depression is bounded on its northern side by a precipitous escarpment running more or less irregular from Kharga oasis in a general westnorthwest direction for a distance of at least $250 \mathrm{~km}$. To the south of this cliff there is a low-lying expanse of sandstone country forming a gentle undulating plain, the general surface of which rises imperceptibly to the south. To the north of the cliff lies the high and almost level limestone plateau, which stretches for a considerable distance beyond the oasis to the north. The exposed sedimentary succession ranges in age from the Middle Campanian to Late Paleocene. Older sediments are cropping out to the south and southeast of the study area starts at the base with variegated claystone, siltstone and sandstone of the Quseir Formation [4], which forms the floor of the Dakhla Depression especially in the central and south eastern parts (Fig. 1). The Quseir Formation [4] also named as the Variegated Shales [5]. [6] and [7] previously inferred limnic conditions in the basal sediments of the formation, where freshwater gastropods, abundant plant debris and other remains of reptiles and dinosaurs are found. [8] stated that the depositional environment of Quseir Formation in Dakhla Depression is possibly fluvial to brackish and restricted marine (glauconitic sediments). 


\section{3- MATERIALS AND METHODS}

Undisturbed and disturbed clayey soil samples were taken from Quseir Shale in the central part of Dakhla Oasis (Teneida, "site I" and Balat "site II"). The depths of boring are $10 \mathrm{~m}$ from the ground surface approximately. A typical subsurface profile is shown in Fig. (2). The studied soil comprises of a top layer (layer A, $2 \mathrm{~m}$ thick) of hard green gypsiferous shale, this layer is followed by a $4 \mathrm{~m}$ thick layer (layer B) of dense yellowish green shale. Layer B is underlain by a very dense green shale (layer $\mathrm{C}, 2 \mathrm{~m}$ thick). Beneath layer $\mathrm{C}$, the material changes to hard reddish gray shale (layer $\mathrm{D}, 2 \mathrm{~m}$ thick). Undisturbed as well as disturbed soil samples were collected from each horizon of the profiles for different geotechnical analysis (Table 1).

Twenty representative samples were taken from, the two previously mentioned boreholes: Tenedia, site I (10 samples), Balat, site II (10 samples). A first method of Quseir Shale soil analysis is the grain-size distribution using sieve analysis and hydrometer test according to classification as can be seen in Fig. 3, the fraction with a grain size below $0.002 \mathrm{~mm}$ is referred to as "clay fraction", regardless of whether clay minerals are present and of what types they are. Atterberg limits were measured for soil classification and as parameters for correlation to predict the soils engineering behavior such as compressibility [9]. According to [10] all samples of the studied clayey soils of Quseir Shale were classified according to the Casagrande's plasticity chart as clay of high plasticity ( $\mathrm{CH}$, Table 1 and Fig. 4).

\section{4- CLAY MINERALOGY}

Twenty representative clayey samples were chosen for mineralogical investigation from the two selected boreholes. Each sample was examined in three forms: as an oriented clay sample (untreated); as an oriented clay sample treated with ethylene glycol; and as an oriented clay sample heated to $550^{\circ} \mathrm{C}$ for $2 \mathrm{~h}$. The clay particle sizes in the samples were $<2 \mathrm{~mm}$. The identification of the clay minerals was based on the basal reflections (001), according to the X-ray powder diffraction results of [11] \& [12], [13], [14], [15] and the ASTM cards.

The relative frequency of the identified clay minerals was calculated according to the method of [16], which is based on measuring the (001) peak height for the individual mineral group considering the total summation of the peak heights of the associated clay minerals which is being equal $100 \%$. Five types of clay minerals were identified throughout the studied sequence, namely kaolinite was the predominant clay mineral present in all samples (58.5.8\%), smectite (22.8\%), illite (9.1\%), illite-smectite mixed-layer $(6.7 \%)$, and chlorite $(2 \%)$ which arranged in a decreasing order of abundance (Table 1, Fig. 5).

\section{5- DETERMINATION OF SHEAR STRENGTH OF QUSEIR SHALE}

To avoid the influence of stress release, the unconsolidated undrained compression triaxial test (UU test) was used. A cylindrical specimen having a length/diameter ratio of 2, is used in the test and is stressed under condition of axial symmetry. The circular 
base has a central pedestal on which the specimen is placed, there being access through the pedestal for drainage or for the measurement of pore water pressure. A perspex cylinder, sealed between a ring and a circular top cap, forms the body of the cell. The top cap has a bush through which the loading ram passes. The cylinder and top cap clamp on to the base, a seal being made by means of an O-ring. The specimen is placed on either a porous or solid disc on the pedestal of the apparatus. A loading cap is placed on top of the specimen and the specimen is then sealed in a rubber membrane.

Table 1. Summary of geotechnical properties of Quseir Shale. Grain size\%, physicochemical properties and class, clay mineral species

\begin{tabular}{|c|c|c|c|c|c|c|c|c|c|c|c|c|c|c|c|c|c|c|c|c|}
\hline \multirow[b]{2}{*}{ 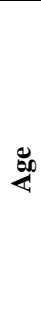 } & \multirow[b]{2}{*}{$\dot{\vec{E}}$} & \multirow[b]{2}{*}{ 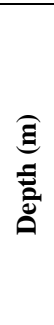 } & \multicolumn{4}{|c|}{ Grain Size Distribution } & \multicolumn{3}{|c|}{$\begin{array}{c}\text { Atterberg } \\
\text { Limits }\end{array}$} & \multirow[b]{2}{*}{ 产 } & \multicolumn{5}{|c|}{$\begin{array}{c}\begin{array}{c}\text { Physico-Chemical } \\
\text { Properties }\end{array} \\
\end{array}$} & \multicolumn{4}{|c|}{$\begin{array}{c}\text { Clay Mineral } \\
\text { Percentages }\end{array}$} & \multirow[b]{2}{*}{ ש: } \\
\hline & & & 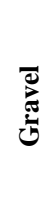 & 节 & 春 & $\stackrel{\vec{J}}{0}$ & ב & $\vec{a}$ & $\bar{a}$ & & $\sum_{j}^{8}$ & $\dot{己}_{0}^{\circ}$ & $\sum_{0}^{\circ}$ & 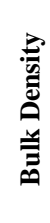 & 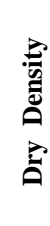 & 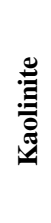 & 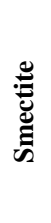 & 总 & 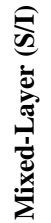 & \\
\hline \multirow{20}{*}{ 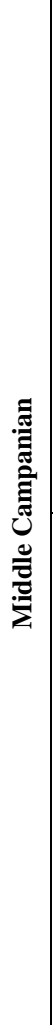 } & \multirow{10}{*}{ 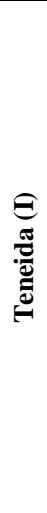 } & 1 & 2.3 & 19.2 & 31.3 & 47.2 & 84 & 35 & 49 & $\mathrm{CH}$ & 12 & 11.9 & 4.1 & 1.92 & 1.6 & 53 & 27 & 15 & 5 & 0 \\
\hline & & 2 & 2.4 & 20.5 & 33.6 & 43.5 & 85 & 33 & 52 & "" & 11 & 12.4 & 4.3 & 1.95 & 1.61 & 54 & 23 & 14 & 9 & 0 \\
\hline & & 3 & 1.8 & 21.7 & 35.3 & 41.2 & 87 & 32 & 55 & "" & 16 & 14.6 & 5.6 & 1.87 & 1.64 & 59 & 22 & 10 & 9 & 0 \\
\hline & & 4 & 1.5 & 22.5 & 37.5 & 38.5 & 89 & 30 & 59 & "'" & 17 & 16.8 & 6.4 & 1.89 & 1.65 & 65 & 20 & 8 & 7 & 0 \\
\hline & & 5 & 2.3 & 17.8 & 37.8 & 42.1 & 82 & 37 & 45 & "" & 19 & 17.2 & 5.4 & 1.94 & 1.67 & 64 & 20 & 7 & 5 & 4 \\
\hline & & 6 & 2.2 & 20.4 & 33.6 & 43.8 & 83 & 33 & 50 & "'" & 18 & 13.3 & 5.8 & 1.91 & 1.68 & 47 & 35 & 9 & 6 & 3 \\
\hline & & 7 & 2.7 & 19 & 39 & 39.3 & 84 & 30 & 54 & "'" & 19 & 14.2 & 6.1 & 1.9 & 1.69 & 52 & 25 & 13 & 5 & 5 \\
\hline & & 8 & 2.4 & 20 & 40 & 37.6 & 85 & 31 & 54 & "'" & 19 & 15.1 & 6.4 & 1.89 & 1.7 & 55 & 23 & 15 & 4 & 3 \\
\hline & & 9 & 1.7 & 22.3 & 42.7 & 33.3 & 86 & 33 & 53 & "'" & 18 & 16.5 & 7.1 & 1.92 & 1.72 & 58 & 20 & 6 & 10 & 6 \\
\hline & & 10 & 1.7 & 24 & 43.5 & 30.8 & 84 & 35 & 49 & "" & 18 & 17.1 & 7.3 & 1.93 & 1.75 & 65 & 22 & 6 & 7 & 0 \\
\hline & \multirow{10}{*}{ 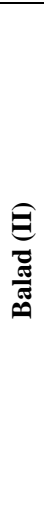 } & 1 & 3.1 & 17.9 & 29.7 & 49.3 & 85 & 34 & 51 & "'" & $\begin{array}{c}9 . \\
8 .\end{array}$ & 13.3 & 5.5 & 1.88 & 1.53 & 54 & 25 & 9 & 8 & 4 \\
\hline & & 2 & 2.7 & 20 & 32.4 & 44.9 & 84 & 34 & 50 & "" & 18 & 14.5 & 5.7 & 1.89 & 1.55 & 56 & 21 & 9 & 14 & 0 \\
\hline & & 3 & 1.4 & 21.9 & 34.5 & 42.2 & 85 & 33 & 52 & "'" & 16 & 15.9 & 6 & 1.94 & 1.6 & 65 & 13 & 8 & 12 & 2 \\
\hline & & 4 & 2.1 & 24 & 37.1 & 36.8 & 86 & 33 & 53 & "'" & 15 & 16.2 & 6.5 & 1.92 & 1.62 & 71 & 14 & 6 & 9 & 0 \\
\hline & & 5 & 2.3 & 18 & 38 & 41.7 & 85 & 31 & 54 & "'" & 18 & 17.2 & 6.7 & 1.92 & 1.65 & 60 & 25 & 8 & 4 & 3 \\
\hline & & 6 & 2.1 & 22.3 & 34 & 41.6 & 85 & 33 & 52 & "'" & 19 & 11.3 & 5.5 & 1.92 & 1.68 & 46 & 37 & 7 & 10 & 0 \\
\hline & & 7 & 2.6 & 19.4 & 39 & 39 & 89 & 31 & 58 & "'" & 16 & 11.8 & 5.8 & 1.94 & 1.7 & 58 & 30 & 8 & 4 & 0 \\
\hline & & 8 & 2.2 & 22 & 39.6 & 36.2 & 87 & 30 & 57 & "'" & 18 & 13.2 & 6 & 1.92 & 1.72 & 60 & 18 & 10 & 6 & 6 \\
\hline & & 9 & 1.5 & 25.4 & 43.1 & 30 & 88 & 32 & 56 & "'" & 16 & 14.7 & 6.2 & 1.91 & 1.75 & 64 & 16 & 9 & 11 & 0 \\
\hline & & 10 & 1.9 & 27 & 45 & 26.1 & 85 & 31 & 54 & "'" & 16 & 15.3 & 6.4 & 1.89 & 1.8 & 67 & 18 & 8 & 4 & 3 \\
\hline \multicolumn{3}{|c|}{$\begin{array}{l}\text { Average } \\
\text { Value }\end{array}$} & $\vec{i}$ & $\stackrel{m}{i}$ & $\stackrel{m}{m}$ & mे & $\stackrel{+}{\infty}$ & $\begin{array}{l}\text { o } \\
\text { ci }\end{array}$ & $\hat{i}$ & J & $\stackrel{+}{\bullet}$ & $\begin{array}{l}\bullet \\
\dot{ \pm}\end{array}$ & $\dot{\vec{n}}$ & $\stackrel{9}{-}$ & I & $\ddot{n}$ & $\grave{i}$ & $a_{a}^{2}$ & $\stackrel{n}{n}$ & i \\
\hline
\end{tabular}

The triaxial tests were carried out on ten undisturbed representative samples. The soil samples were prepared by cutting it by mechanical saw machine from a hard 
soil block to pieces of dimensions $3.81 \mathrm{~cm}$ diameter and $7.62 \mathrm{~cm}$ high. Then the samples were carefully placed in the triaxial cell, cell pressure $\left(\sigma_{3}\right)$ of $0.5,1,1.5$ and $2 \mathrm{~kg} / \mathrm{cm}^{2}$ were applied on each sample, and the deviator stresses $\left(\sigma_{\mathrm{d}}\right)$ were measured The results were obtained and reported in table (2) and Figs. (6a-d). The shear strength of a soil $\tau_{\mathrm{f}}$ could by expresses by:

$$
\tau_{f}=c^{-}+\sigma^{-} \tan \phi
$$

where: $\tau_{\mathrm{f}}=$ Shear strength, $\mathrm{c}^{-}=$Effective cohesion stress, $\sigma^{-}=$Effective normal stress $\phi^{-}=$Angle of internal friction.

The shear strength characteristics of the studied samples as major stress $\sigma_{1}$, cohesion I and angle of internal friction $(\phi)$ were ummarized in table (2) and figures (6-9). These measurements show that major stress $\sigma_{1}$ ranged between $6.9 \mathrm{~kg} / \mathrm{cm}^{2}$ in samples I-1 and $8.5 \mathrm{~kg} / \mathrm{cm}^{2}$ in samples II-10 in the case of cell pressure $\left(\sigma_{3}\right) 2 \mathrm{~kg} / \mathrm{cm}^{2}$. Also, it is clear that the major stress $\sigma_{1}$ values increase with increasing the depth (Table 2). The cohesion I of the studied samples fluctuates from $0.5 \mathrm{~kg} / \mathrm{cm}^{2}$ in samples $\mathrm{I}-1$ to $1.0 \mathrm{~kg} / \mathrm{cm}^{2}$ in samples II-10. The values of $\mathrm{C}^{-}$increase with increasing of the depth especially in Site I (Table 2). Using the Mohr 's circles, the determined values of the angle of internal friction $(\phi)$ of the studied samples vary from $20^{\circ}$ in sample II- 8 to $26^{\circ}$ in samples I-9.

Table 2. The triaxial testing data and results of the studied Quseir Varigated Shale in Dakhla Oasis.

\begin{tabular}{|c|c|c|c|c|c|c|c|c|c|c|c|}
\hline \multirow{2}{*}{$\begin{array}{c}\text { Depth } \\
\text { (m) }\end{array}$} & \multicolumn{5}{|c|}{ Teneida (I) } & \multirow{2}{*}{$\begin{array}{c}\text { Depth } \\
\text { (m) }\end{array}$} & \multicolumn{5}{|c|}{ Balat (II) } \\
\hline & $\sigma_{3}$ & $\sigma_{d}$ & $\sigma_{1}$ & $\mathbf{C}^{-}$ & $\phi$ & & $\sigma_{3}$ & $\sigma_{d}$ & $\sigma_{1}$ & $\mathbf{C}^{-}$ & $\phi$ \\
\hline \multirow{4}{*}{1} & 0.5 & 1.6 & 2.1 & \multirow{4}{*}{0.5} & \multirow{4}{*}{22} & \multirow{4}{*}{2} & 0.5 & 1.7 & 2.2 & \multirow{4}{*}{0.5} & \multirow{4}{*}{21} \\
\hline & 1 & 2.9 & 3.9 & & & & 1 & 3.1 & 4.1 & & \\
\hline & 1.5 & 4 & 5.5 & & & & 1.5 & 4.4 & 5.9 & & \\
\hline & 2 & 4.9 & 6.9 & & & & 2 & 6.1 & 8.1 & & \\
\hline \multirow{4}{*}{3} & 0.5 & 1.7 & 2.2 & \multirow{4}{*}{0.6} & \multirow{4}{*}{25} & \multirow{4}{*}{4} & 0.5 & 1.8 & 2.3 & \multirow{4}{*}{0.6} & \multirow{4}{*}{23} \\
\hline & 1 & 3 & 4 & & & & 1 & 3.3 & 4.3 & & \\
\hline & 1.5 & 4.1 & 5.6 & & & & 1.5 & 4.4 & 5.9 & & \\
\hline & 2 & 5.1 & 7.1 & & & & 2 & 6.2 & 8.2 & & \\
\hline \multirow{4}{*}{5} & 0.5 & 1.8 & 2.3 & \multirow{4}{*}{0.7} & \multirow{4}{*}{24} & \multirow{4}{*}{6} & 0.5 & 1.6 & 2.1 & \multirow{4}{*}{0.5} & \multirow{4}{*}{26} \\
\hline & 1 & 3 & 4 & & & & 1 & 3.2 & 4.2 & & \\
\hline & 1.5 & 4 & 5.5 & & & & 1.5 & 4.5 & 6 & & \\
\hline & 2 & 5.2 & 7.2 & & & & 2 & 5.9 & 7.9 & & \\
\hline \multirow{4}{*}{7} & 0.5 & 1.9 & 2.4 & \multirow{4}{*}{0.7} & \multirow{4}{*}{21} & \multirow{4}{*}{8} & 0.5 & 1.7 & 2.2 & \multirow{4}{*}{0.6} & \multirow{4}{*}{20} \\
\hline & 1 & 3.3 & 4.3 & & & & 1 & 3 & 4 & & \\
\hline & 1.5 & 4.7 & 6.2 & & & & 1.5 & 4.1 & 5.6 & & \\
\hline & 2 & 5.9 & 7.9 & & & & 2 & 5.9 & 7.9 & & \\
\hline \multirow{4}{*}{9} & 0.5 & 2.1 & 2.6 & \multirow{4}{*}{0.9} & \multirow{4}{*}{26} & \multirow{4}{*}{10} & 0.5 & 1.9 & 2.4 & & \\
\hline & 1 & 3.6 & 4.6 & & & & 1 & 3.1 & 4.1 & 1 & 24 \\
\hline & 1.5 & 4.8 & 6.3 & & & & 1.5 & 4.3 & 6 & & \\
\hline & 2 & 6.3 & 8.3 & & & & 2 & 6.5 & 8.5 & & \\
\hline
\end{tabular}




\section{6- FACTORS AFFECTING UNDRAINED SHEARING STRENGTH OF THE QUSEIR SHALE}

It is evident from the previous mentioned practical works of geotechnical testing of the clayey soils of Quseir Varigated Shale in Dakhla Oasis that there is a strong mutual relation between some measurements and undrained shearing parameters. So that, more lights will throw on this interacting relation. These factors can be classified as:

\section{1- EFFECT OF GRAIN SIZE DISTRIBUTION}

The results of shear testing show that the grain size plays an important role in the measured shear strength characteristics of the studied samples. Sand as well as silt fractions have a close direct proportional relation with major stress $\left(\sigma_{1}\right)$ of the studied samples in the case cell pressure $\left(\sigma_{3}\right) 2 \mathrm{~kg} / \mathrm{cm}^{2}$ while clay fraction has an indirect relation (Figs. 7, 8 and 9). The measured effective cohesion $\left(\mathrm{C}^{-}\right)$has a close direct proportional relation with clay fractions but indirect relation with sand and silt fractions (Figs. 10, 11 and 12).

El-Ghonaimy [17] stated that with the increase of clay fractions, the plasticity index will also increase, then greater binding forces will be developed causing an increase in the soil strength. Also the calculated internal friction angle of the studied samples shows a direct relation with the sand fraction percent (Fig. 13).

\section{2- EFFECT OF CLAY MINERALOGY}

Mechanical properties of cohesive soils depend on the mineral composition and conditions in the environment [18] and [19]. It clearly seen that the clay minerals play a vital role in the measured major stresses of the studied samples. The measured major stress $\left(\sigma_{1}\right)$ has a close direct proportional relation with the kaolinite content of the studied samples (Fig. 14). This may be attributed to the nature of kaloinite particles which have the largest grain size among the examined clay minerals species. The kaolinite particles have the smallest anisometry, i.e. the smallest diameter-thickness ratio. The kaolinite particles thus have a relatively large edge surface.

On the other hand, kaolinite has a distinct distribution of the charge, with one highly charged and one uncharged basal plane. This led to high major stress for both the sodium and the calcium forms [20]. The relatively high major stress of kaolinite comes principally from the intergranular friction [1]. Smectite has a direct proportional relation the measured effective cohesion $\mathrm{C}^{-}$(Fig. 15).

\section{3- EFFECT OF INITIAL WATER CONTENT}

Khera and Krizek [21] and [22] stated that the undrained shear strength is independent of change in total stress unless a change in water content occurs and postulated that the 
water content is a function of the maximum principle consideration stress alone. The results of the measuring tests show a significant a closed indirect proportional relation has been seen between the initial water content and major stress $\sigma_{1}$ (Fig. 16).

Koumoto and Houlsby [23] found out that the relationship between the undrained shear strength and the quantity of water contained in soils could be expressed by the nonlinear function.

\section{4- EFFECT OF DRY DENESITY AND CALCIUM CARBONATE CONTENT}

The major stress $\left(\sigma_{1}\right)$ increases with increasing the dry density and calcium carbonate content of the studied soils (Figs. 17 and 18). Tsiambaos [24] concluded that the increase in calcium carbonate content for clayey soils cases a decrease in plasticity index and a significant increase in shear strength.

\section{5- EFFECT OF DEPTH}

The results reflect a direct proportional relation between depth of the selected samples and their measured major stress $\left(\sigma_{1}\right)$, cohesion (C) (Table 2). At the same time the major stress have a general tendency to increases with increasing of cell pressure. This may be due to a reorientation of plate-like clay particles parallel to the bedding plane under the effect of axial stress of sediment that increase with depth. This results in a direct decreasing in porosity as well as decreasing in initial water content so that the measured major stress will increase (natural consolidation) [25].

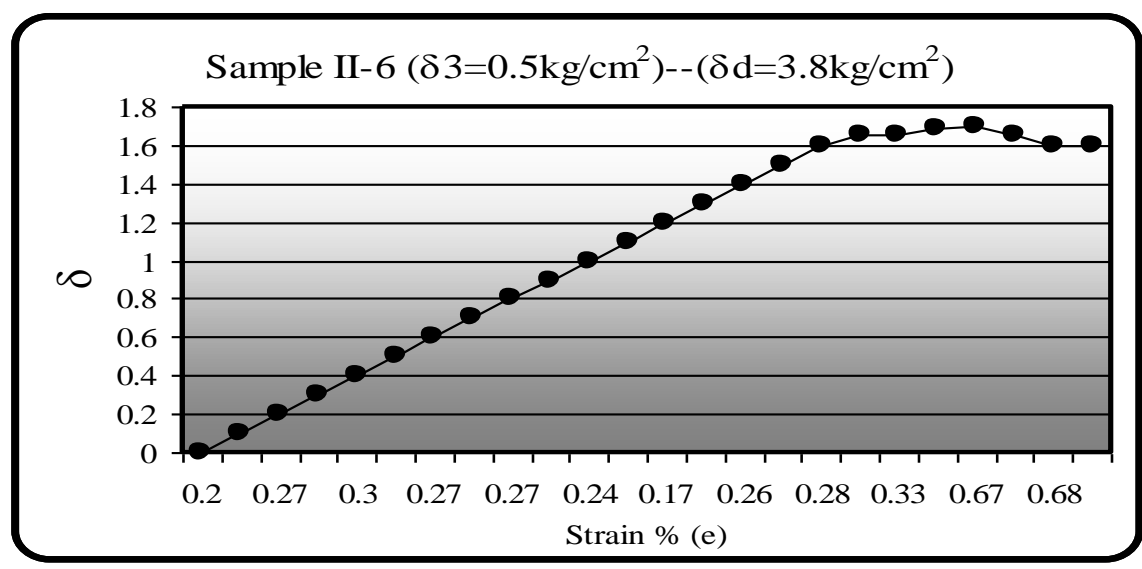

Fig. 6a 


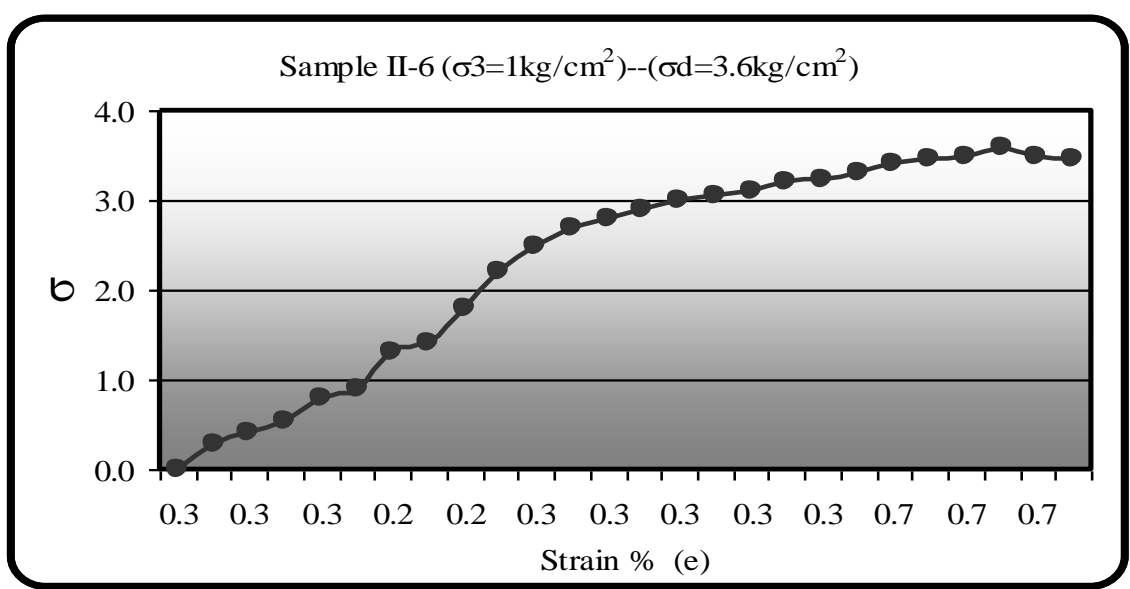

Fig. $6 \mathrm{~b}$

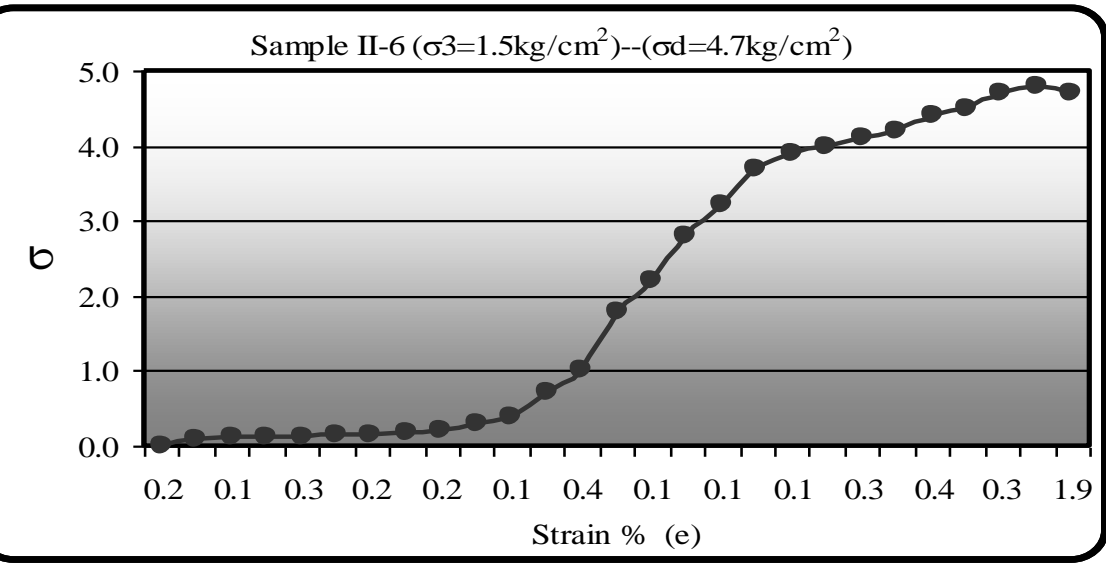

Fig.6c

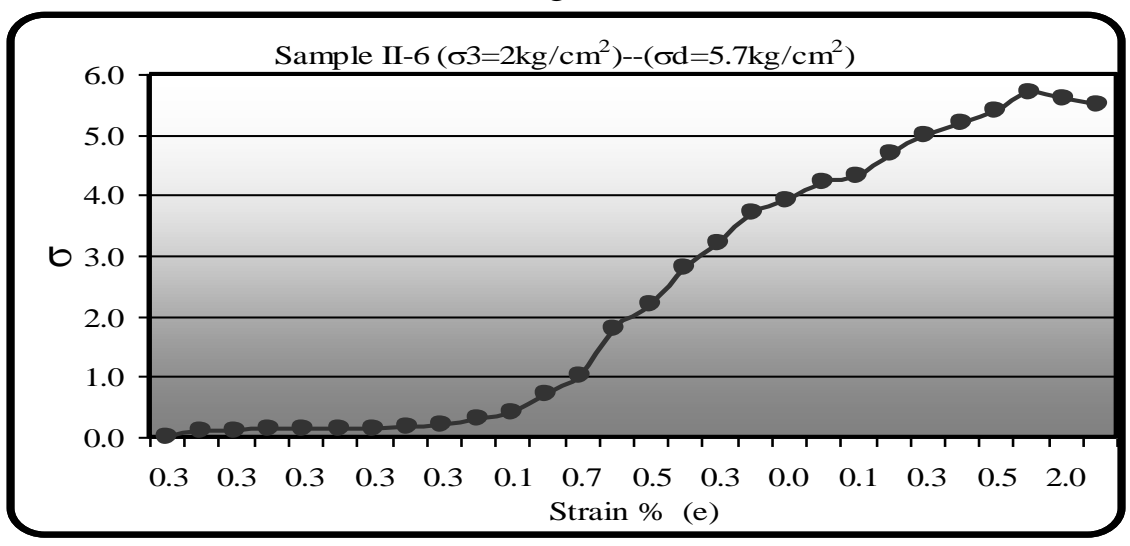

Fig.6d

Fig. (6) The result of triaxial testing with different cell pressures 


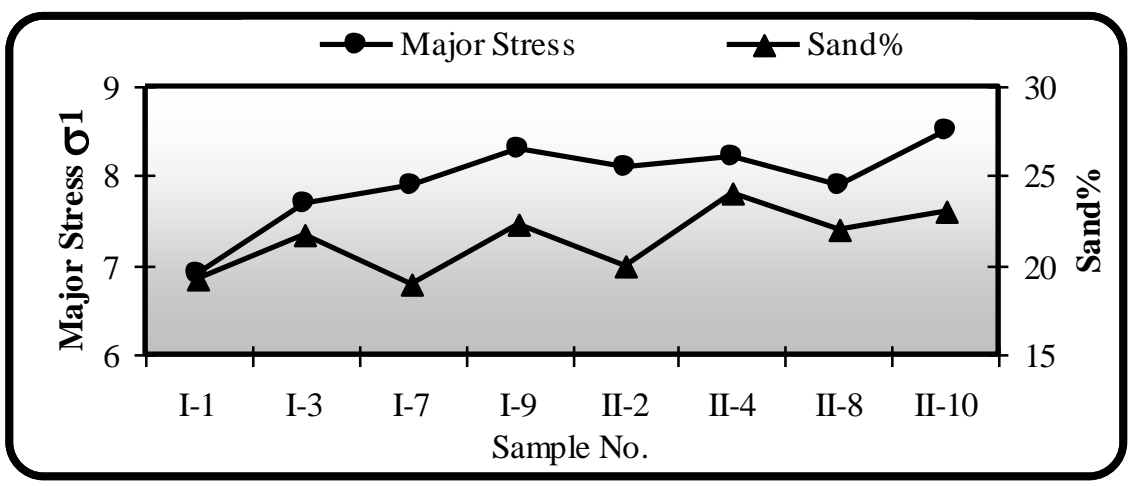

Fig. 7. Relation between sand $\%$ and major stress $\left(\mathrm{kg} / \mathrm{cm}^{2}\right)$ of Quseir Shale.

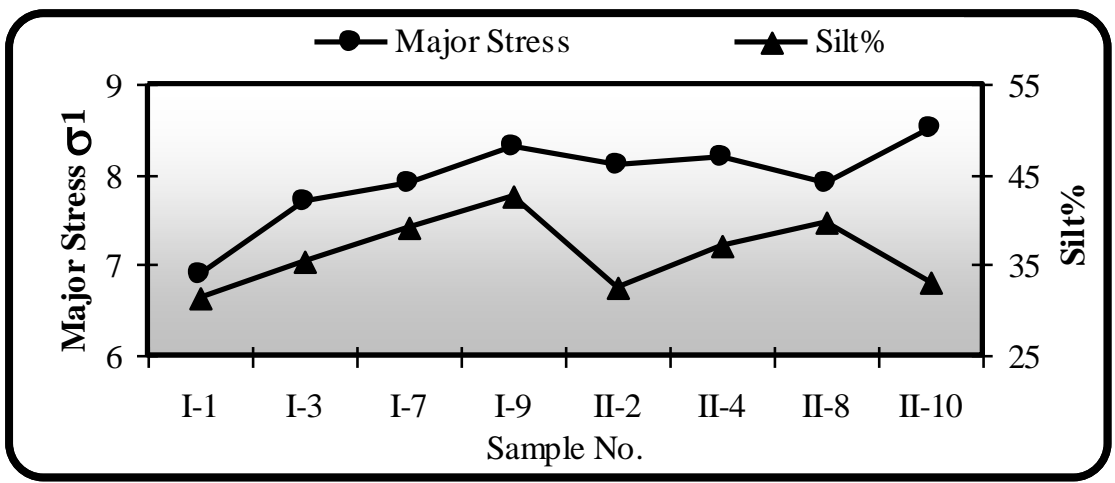

Fig. 8. Relation between silt\% and major stress $(\mathrm{kg} / \mathrm{cm} 2)$ of Quseir Shale.

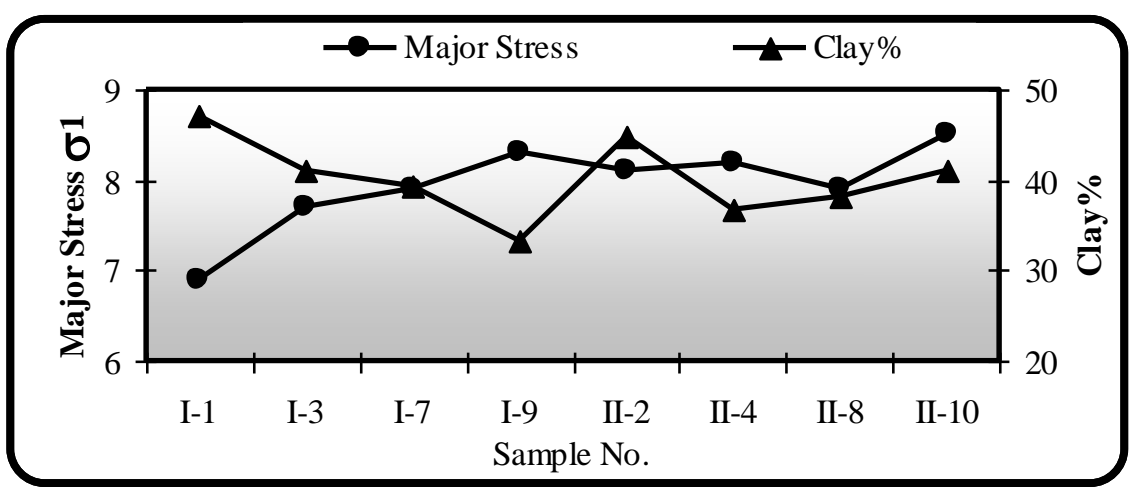

Fig. 9. Relation between clay\% and major stress $(\mathrm{kg} / \mathrm{cm} 2)$ of Quseir Shale. 


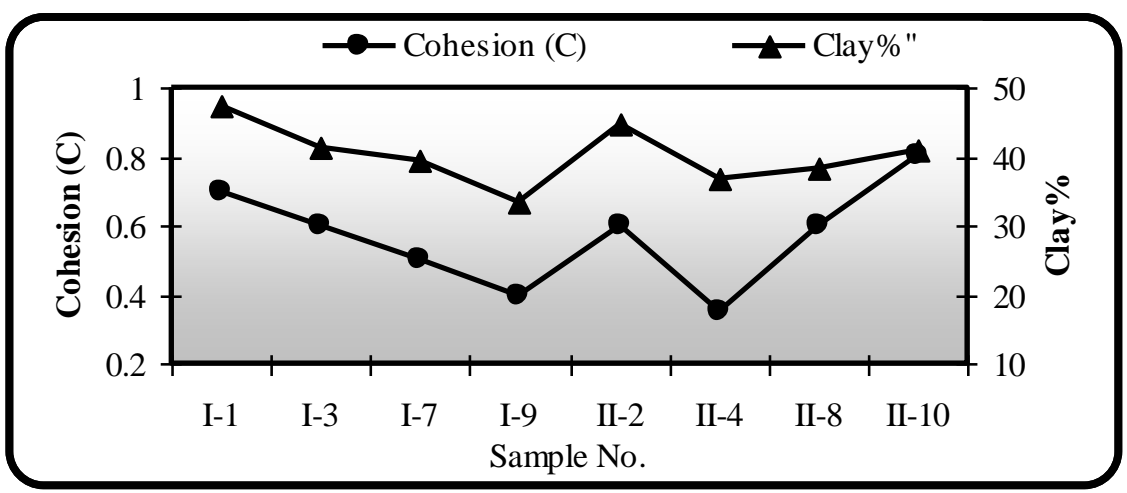

Fig. 10. Relation between clay\% and cohesion $\left(\mathrm{kg} / \mathrm{cm}^{2}\right)$ of Quseir Shale.

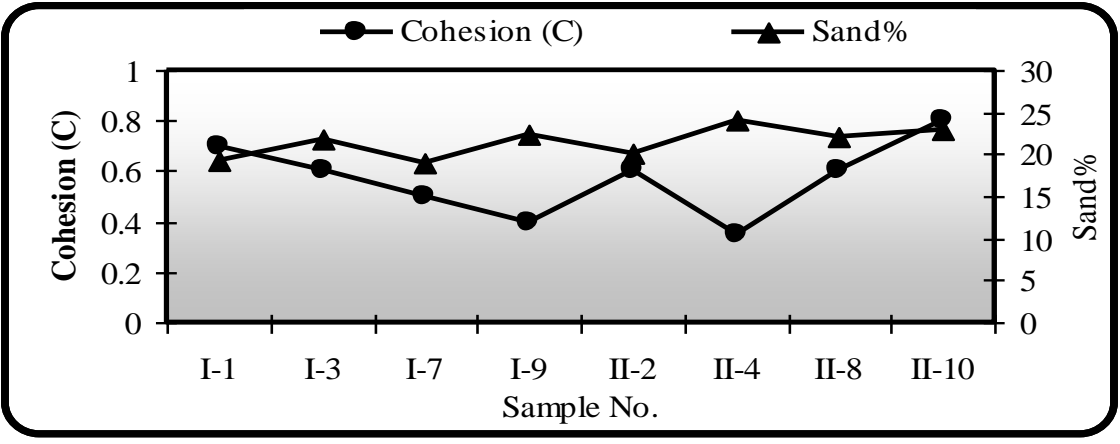

Fig. 11. Relation between sand\% and cohesion $(\mathrm{kg} / \mathrm{cm} 2)$ of Quseir Shale.

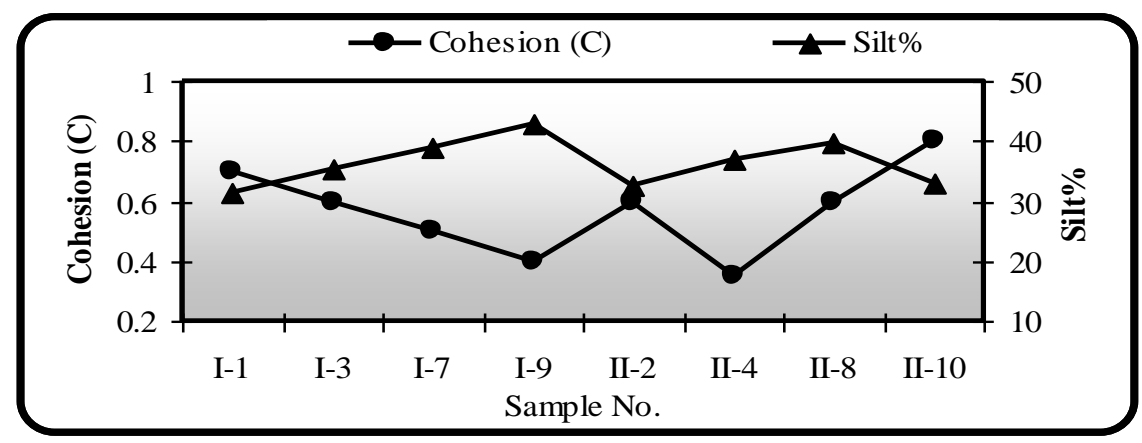

Fig. 12. Relation between silt\% and cohesion $(\mathrm{kg} / \mathrm{cm} 2)$ of Quseir Shale. 


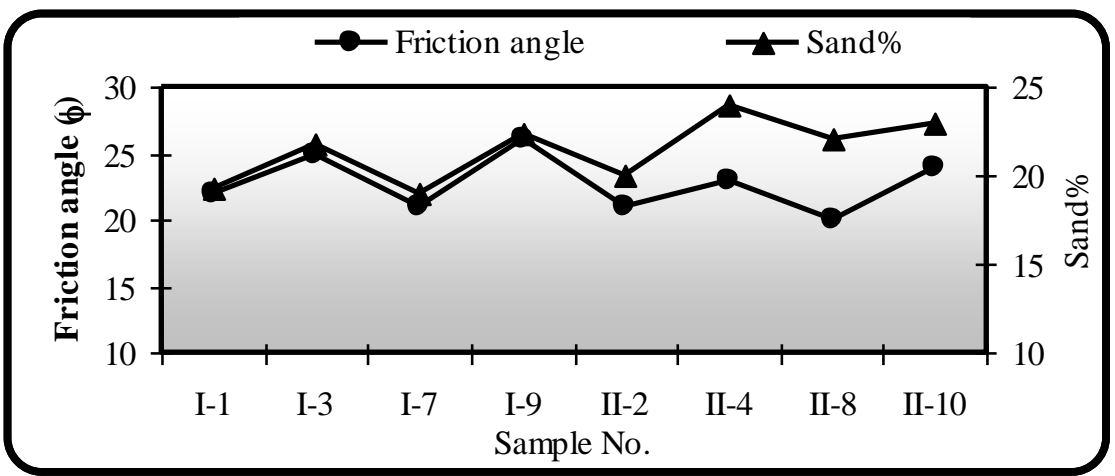

Fig. 13. Relation between sand\% and internal friction angle $(\phi)$ of Quseir Shale.

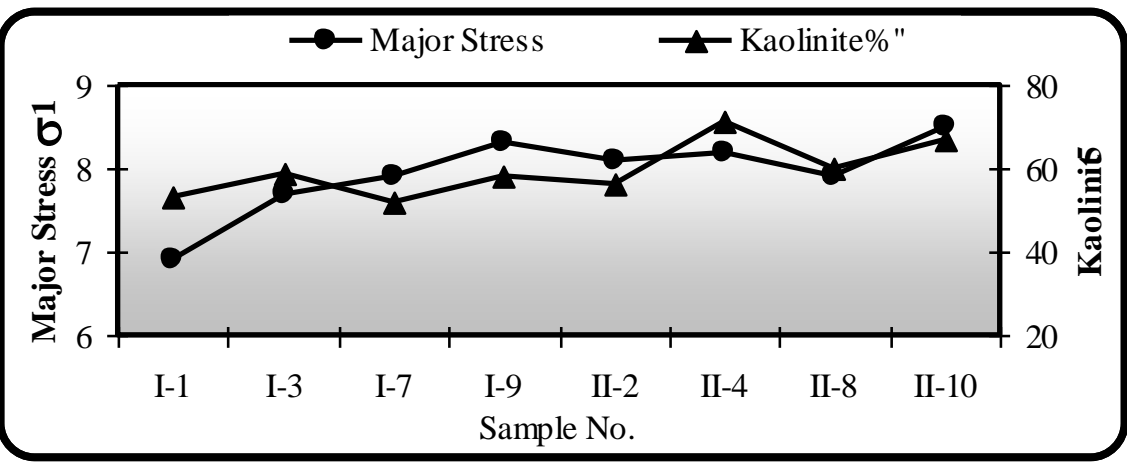

Fig. 14. Relation between kaolinite and major stress $\left(\mathrm{kg} / \mathrm{cm}^{2}\right)$ of Quseir Shale.

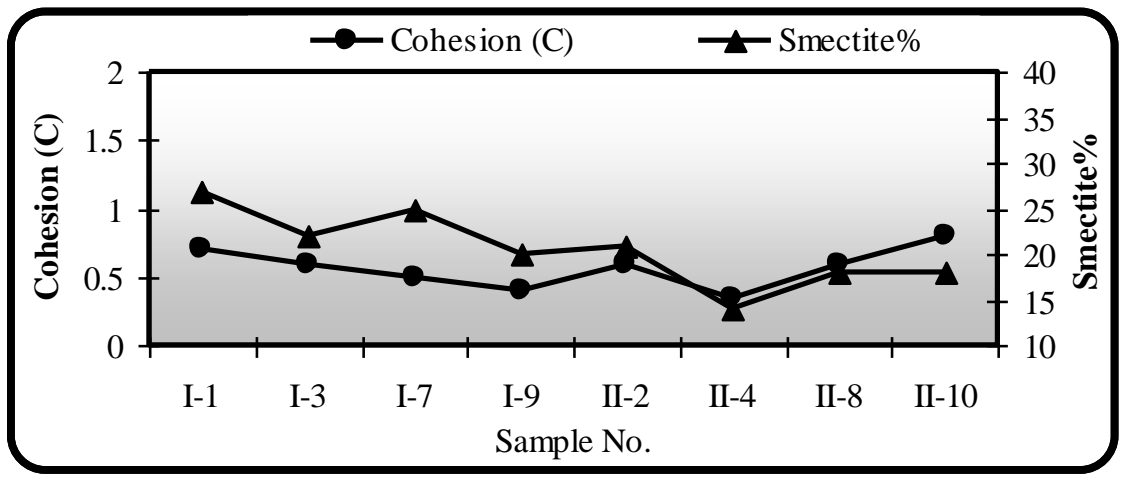

Fig. 15. Relation between smectite\% and cohesion $(\mathrm{kg} / \mathrm{cm} 2)$ of Quseir Shale. 


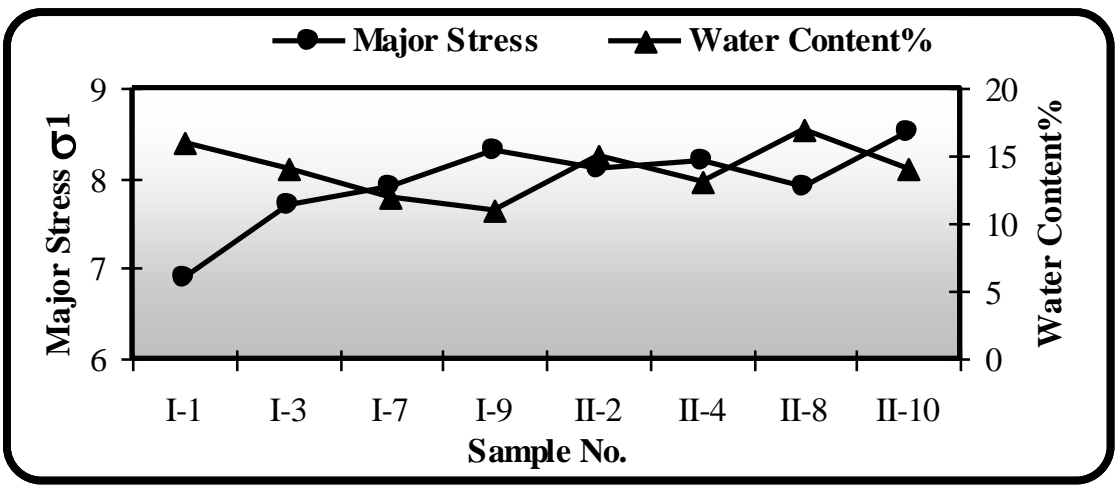

Fig. 16. Relation between initial water \% and major stress $\left(\mathrm{kg} / \mathrm{cm}^{2}\right)$ of Quseir Shale.

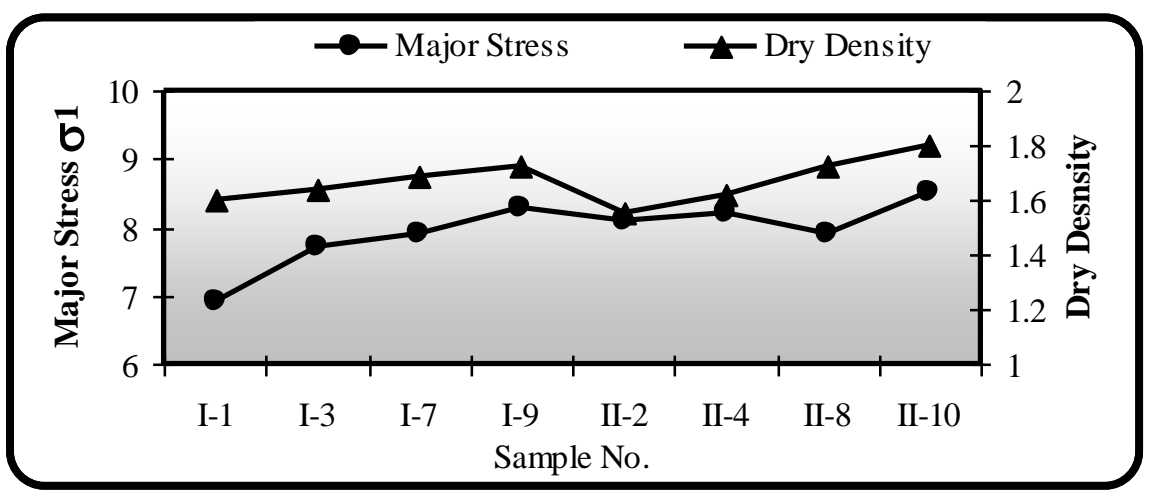

Fig. 17. Relation between dry density and major stress $\left(\mathrm{kg} / \mathrm{cm}^{2}\right)$ of Quseir Shale.

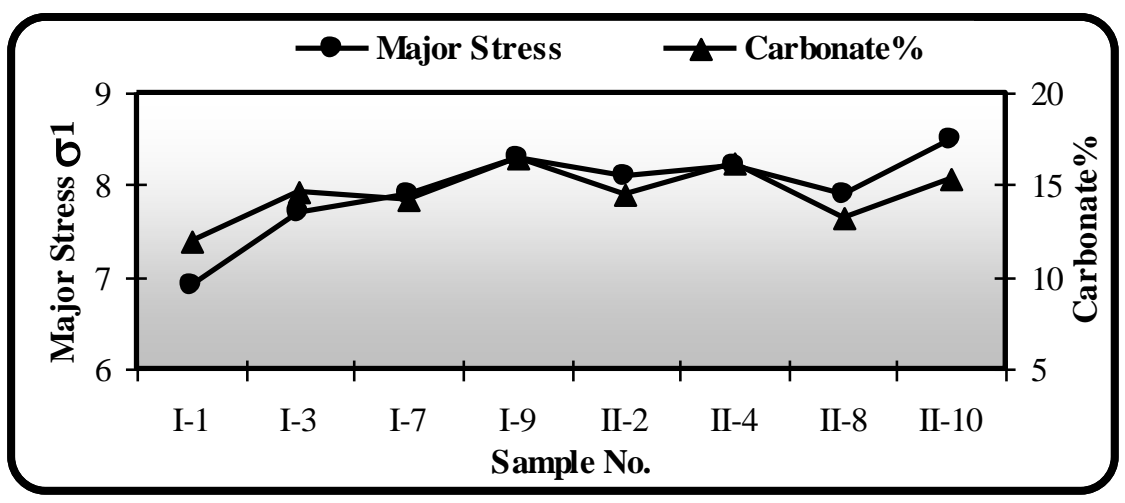

Fig. 18. Relation between carbonate and major stress $\left(\mathrm{kg} / \mathrm{cm}^{2}\right)$ of Quseir Shale. 


\section{7- CONCLUSIVE REMARKS}

The main significant observations are:

1. The shearing behavior of soils is of major concern for engineers, since the solution of stability problems in foundation engineering requires knowledge of the shearing strength of the underlying soil.

2. The Quseir Shale in the central part of Dakhla Oasis consists of four layers (green gypsiferous shale graded downward into yellowish green shale, green shale and reddish gray shale).

3. The clay minerals of this soil are of five species namely kaolinite, smectite, illite, illite-smectite mixed-layer and chlorite.

4. The measured major stress $\left(\sigma_{1}\right)$ has a close direct proportional relation with sand $\%$, silt \%, kaolinite \%, depth and calcium carbonate content which make as cement.

5. The measured effective cohesion $\left(\mathrm{C}^{-}\right)$has a close direct proportional relation with clay fractions, and initial water content. Also, it has a same relation with smectite content. The semctite group minerals have relatively smaller size so they considered as a matrix for coarser fractions.

6. The internal friction angle $(\phi)$ of these soils has a direct proportional relation with sand fractions.

\section{REFERENCES}

1. Muller-Vonmoos, M. and Loken, T. (1989): The Shearing Behaviour of Clays. Applied Clay Science, vol. 4, pp. 125-141.

2. Sharma, S.S. and Fahey, M. (2003): Evaluation of cyclic shear strength of two cemented calcareous soils. Journal of Geotechnical and Geoenvironmental Engineering, Vol. 129, No. 7, July 1, pp. 608-618.

3. Russell, D.J., Denness, B. and McCann, D.M. (1978): Shear -strength anisotropy variation in weathered Oxford Clay. Engineering Geology, 12, pp. 337 344.

4. Youssef, M.I. (1957): Upper Cretaceous rocks in Kosseir area. Bulletin Institute Desert Egypt 7 (2), 35-54.

5. Said, R., (1962): The geology of Egypt. Elsevier Publishing Company, Amsterdam, 377p.

6. Awad, G.H. and Ghobrial, M.G. (1965): Zonal stratigraphy of the Kharga Oasis. Geol. Surv. Egypt, paper 34, 77p.

7. Hendriks, F , Luger, P , Kallenbach, H and Schroeder, J H (1984): Stratigraphical and sedimentological framework of the Kharga-Sinn el-Kaddab Stretch (Western and Southern part of the Upper Nile Basin), Western Desert, Egypt Berliner geowtss Abh A 50, pp. 17-151.

8. Hermina, M.H. (1990): The surroundings of Kharga, Dakhla and Farafra Oases. In Said, R. (Ed.) The geology of Egypt. Balkema, Rotterdam, pp.259-292.

9. Abdullah, W.S., Alshibli, K.A. and Al-Zou'bi, M.S. (1999): Influence of pore water chemistry on the swelling behavior of compacted clays. Applied Clay Science, vol., 15 pp. 447-462. 
10. British Standard, (1990): British Standard 1377, Methods of Test for Soils for Civil Engineering Purposes. British Standard Institution, London.

11. Weaver, C.E. (1958): Geological interpretation of clay minerals in sedimentary rock, Clay Minerals., $5^{\text {th }}$ Nat. Conf., Nat. Res. Counsel Publ., Vol. 566, pp. 159175.

12. Weaver, C.E. (1967): The significance of clay minerals in sediments, in fundamental aspects of petrol. Geochemistry, Nagy and Colombo, Ed. Elsevier Publ. Amstrdam, pp. 37-75.

13. Carrol, D. (1970): Clay minerals: a guide to their X-ray identification. Geol. Soc. Am. Spec. paper No. 126, 75p

14. Millot, G. (1970): Geology of Clays. Springer Verlag, New York, 429P.

15. Chen, P.Y. (1977): Table of key lines in $x$-ray powder identification patterns of minerals in clays and associated rocks. Ind. Geol. Surv., paper No. 21, pp. 67.

16. Griffin, G. (1971): Interpretation of x-ray diffraction data, In: Procedure in Sedimentary Petrology. (Edt. Carver, R. E.) Willey-Interscience, New York, pp. 541-568.

17. El-Ghonaimy, A.Y. (1992): Prediction of shear strength for Port Said soft clay. M. Sc. Thesis Faculty of Engineering, Cairo University, 144p.

18. Koumoto, T. (1989): Dynamic analysis of t0068e fall cone test. J. Jpn Soc. Irrigation, Drainage and Reclamation Engng, Vol. 144, pp. 51-56.

19. Koumoto, T. (1990): Determination of the both liquid and plastic limits of clay by the fall cone test. J. Jpn Soc. Irrigation, Drainage and Reclamation Engng, Vol.146, pp. 95-100.

20. Lagaly, G. (1989): Principles of flow of kaolin and bentonite dispersions. Appl. Clay Sci., 4: 105-123.

21. Khera, R.P., and Krizek, R.J. (1968): Effect of principle consolidation stress difference on undrained shear strength. J. Soil. And Foundation, vol., VIII, No.., 1, pp. 1-17, The Japanese Society of Soil Mech. And Found. Eng.

22. Lambe, T.W., and Whitman, R.V. (1969): Soil Mechanics, Wiley Eastern Limited, New Delhi.

23. Koumoto, T. and Houlsby, G.T. (2001): Theory and practice of the fall cone test. Geotechnique, 2001, LI, No. 8, 701-712.

24. Tsiambaos, G. (1991): Correlation of mineralogy and index properties with residual strength of Iraklion marls. Engineering Geology 30 (1991) 357-369.

25. Craig, R.F. (1979): Soil mechanics. $2^{\text {nd }}$ (ed.) ELBS, London 314p. 
العوامل الجيوتقتية آلتي تؤثر في مقاومة طقلة القصير للقص, بواحة الداخلة الصحراء الغربية, مصر.

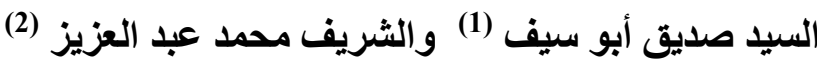

(2) كلية الهندسة قسم مدني - جامعة أسيوط (1) كلية العلوم قسم الجيولوجيا - جامعة سو هائ أبون

هذه الدراسة تتتاول تأثير العوامل الجيوتقنية على مقاومة طفلة القصبر للقَص المنواجدة بواحة

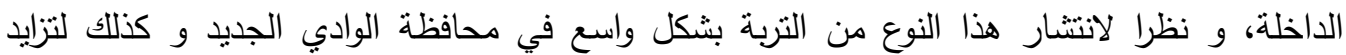

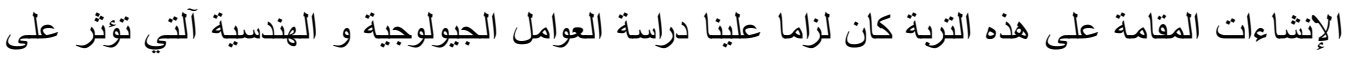

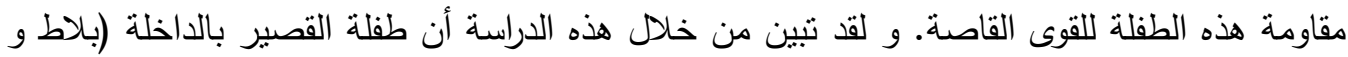

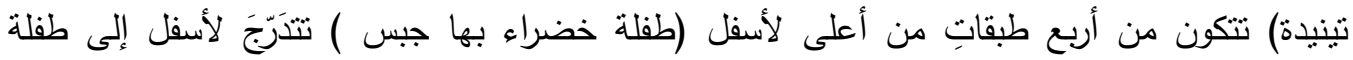

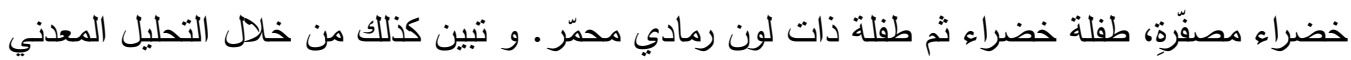

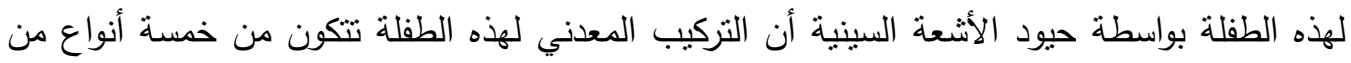

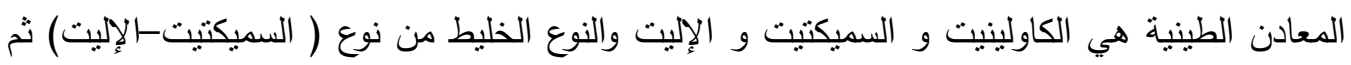

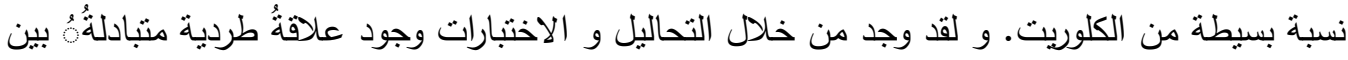

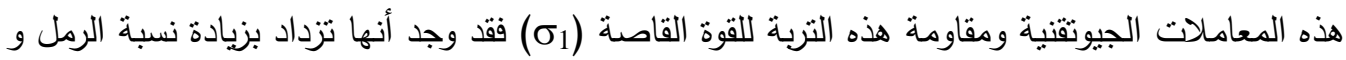

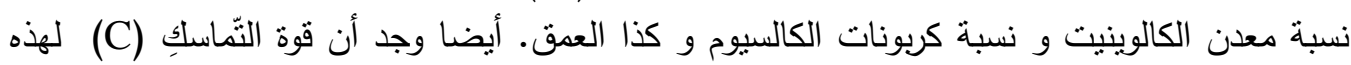

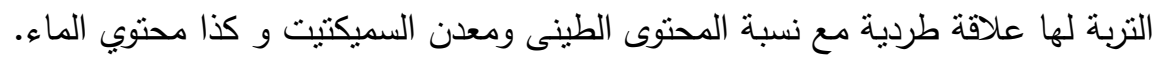

